\title{
Chiara Ferragni - marka luksusowa i ikona współczesnego świata mody. Studium przypadku*
}

\section{Wprowadzenie}

Chiara Ferragni to założycielka najpopularniejszego bloga modowego - The Blonde Salad, który stał się luksusową marką, znaną na całym świecie, nie tylko wśród osób związanych z branżą modową ${ }^{1}$. W 2014 roku blogerka musiała podjąć działania, które miały pozwolić jej na jak najlepsze „zmonetyzowanie” jej portalu oraz autorskiej kolekcji butów Chiara Ferragni Collection. W 2013 roku Ferragni wraz ze swoim ówczesnym partnerem oraz współtwórcą marki Riccardo Pozzolim podjęli decyzję o transformacji bloga w „e-magazyn lifestylowy”, który jednocześnie miał stać się marką ekskluzywną. Oznaczało to, że Ferragni ma współpracować tylko z wybranymi „brandami luksusowymi”, co w nieunikniony sposób miało zredukować jej początkowe przychody, a w przyszłości przynieść większe i trwalsze zyski. Ferragni i jej partner rozważali więc zmianę modelu biznesowego The Blonde Salad Blog generują-

* Artykuł został oparty na studium przypadku opracowanym przez pracowników naukowych Harvard Business School: A. Keinan, K. Maslauskaite, S. Crener, V. Dessain, The Blonde Salad, Harvard Business School Case 515-074, January 2015, https://cb.hbsp.harvard.edu/cbmp/content/sample/515074-PDF-ENG (dostęp: grudzień 2017).

${ }^{1}$ R. Sanderson, Chiara Ferragni - the Italian influencer who built a global brand, https://www. ft.com/content/9adce87c-2879-11e9-a5ab-ff8ef2b976c7 (dostęp: 5.02.2019). 
cego przychody tylko w obrębie rynku internetowego. Jaka strategia została przyjęta, aby osiągnąć założony cel? Czy linia obuwnicza Chiara Ferragni Collection — jako osobna firma, o innej strukturze własności - powinna zostać połączona z blogiem? A może te dwie platformy powinny być prowadzone oddzielnie? Poniższy artykuł pozwala zrozumieć fenomen oraz model marek: The Blonde Salad, Chiara Ferragni Celebrity oraz Chiara Ferragni Collection w oparciu o studium przypadku opisane w 2014 roku przez autorów z Harvard Business School (Keinan, Anat, Maslauskaite, Crener, Dessain 2015) oraz na podstawie analizy aktów komunikacji Ferragni i jej zespołu TBS Crew (The Blonde Salad Crew) w latach 2014-2018 na Instagramie i na blogu.

\section{Moda i media społecznościowe}

Media społecznościowe to według Andreasa Kaplana i Michaela Haenleina „grupa bazujących na internetowych rozwiązaniach aplikacji, które opierają się na ideologicznych i technologicznych podstawach Web 2.0, które to umożliwiają tworzenie i wymianę wygenerowanych przez użytkowników treści”2. Media społecznościowe służą do komunikacji i wymiany informacji z innymi użytkownikami sieci. Największą zaletą Internetu oraz mediów, które za jego pomocą powstają, jest globalny zasięg, który zmienił na zawsze rynek oraz jakość komunikacji. Angus McLeod uważa, że:

żadne inne środki reklamy — prasa, radio czy lokalne kampanie promocyjne - nie dają szansy dotarcia do równie wielu potencjalnych klientów spoza najbliższego otoczenia. W tym wypadku mały, dopiero co powstający, biznes ma o wiele większe szanse na stworzenie reklamy w Internecie i pozyskanie klientów zarówno lokalnie, jak i globalnie. W XXI wieku te nowe, superpotężne narzędzia marketingowe nie mogą być ignorowane przez żaden szanujący się biznes ${ }^{3}$.

Chociażby z tego względu blogi, a także media społecznościowe odgrywają ogromną w rolę nie tylko w życiu marketerów, ale także w życiu każdego człowieka, a jedną z najbardziej zdominowanych przez media społecznościowe branż jest szeroko pojęta moda. Słownik języka polskiego proponuje dwie definicje mody, po pierwsze to „sposób ubierania się, czesania i makijażu popularny w jakimś okresie lub miejscu”", po drugie „krótkotrwała popularność czegoś nowego w jakiejś dziedzinie” ${ }^{5}$. W Encyklopedii PWN moda została zdefiniowana jako „[łac.], socjol. powszechnie przyjęty zwyczaj (dotyczący zwłaszcza stylu, sposobu ubierania się, zachowywania), ulegający częstym zmianom; jeden z głównych regulatorów zachowania się jednostek w spo-

${ }^{2}$ M. Haenlein, A.M. Kaplan, Users of the world, unite! The challenges and opportunities of Social Media, „Business Horizons” 2010, nr 1 (53).

3 A. McLeod, Marketing internetowy w praktyce, przeł. P. Obmiński, Gliwice 2005.

${ }^{4}$ Moda, [hasło w:] Słownik języka polskiego, https://sjp.pwn.pl/szukaj/moda.html (dostęp: 7.12.2017).

${ }^{5}$ Ibidem. 
łeczeństwach nowoczesnych; uleganie modzie jest zarówno przejawem konformizmu w stosunku do wybranych grup, jak i chęci wyróżnienia się z tłumu”6. Badaczka mody i autorka bloga modologiablog.pl — Dominika Łukoszek definiuje modę jako pewien mechanizm, któremu możemy — na dobry początek modologicznych rozważań — przypisać wymienione wyżej cechy, czyli krótkotrwałość (czy jakaś moda trwa wiecznie?), popularność (jeśli coś jest niepopularne, to chyba $\mathrm{z}$ założenia nie może być modne, a jak coś jest modne, to podziela to jakaś większa grupa osób), zmienność (zapewne związana z krótkotrwałością, coś, co trwa stale, nie jest określane mianem mody) oraz funkcja regulatora zachowania jednostki (czytam pewnie za dużo prasy kolorowej, bo pierwsze co przyszło mi do głowy, to wskazówki typu: jak chcesz być »in « ubierz groszki, bo ubranie kratki sprawi, że będziesz »out «?

Podsumowując, należy przytoczyć jeszcze jeden cytat z książki Why fashion matters?. Jej autor wskazuje, że „moda ma znaczenie. Dla ekonomii, społeczeństwa i każdego z nas z osobna. To, co nosimy, mówi o tym, kim jesteśmy i kim chcemy być, szybciej niż cokolwiek innego. Moda jest jednocześnie najbardziej bezpośrednią i intymną formą ekspresji własnego $j a$ "8. W poniższym artykule przyjęto, że moda jest technicznym sposobem wyrażania „czegoś” przez „kogos” lub przez „coś” w danym czasie i miejscu. To uproszczenie wskazuje na interakcję osoba - miejsce - czas. Aktualnie głównymi narzędziami, które służą do wyrażania siebie, do pokazywania swoich stylizacji, a także panujących trendów przez osoby lub marki ze świata mody, są blogi oraz media społecznościowe (w tym przypadku Instagram). Narzędzia te ukazują daną osobę lub rzecz, coś, co z jakiegoś powodu dla autora wybranego wpisu jest ważne lub czym autor chce się w danej chwili podzielić z szerszą publicznością.

W niniejszym artykule zanalizowany został model prowadzenia bloga modowego na platformie Instagram oraz fenomen Chiary Ferragni, która stała się współczesną ikoną mody.

Ze względu na ciągłe przemiany społeczne, technologiczne - zachodzące zarówno w świecie rzeczywistym, jak i wirtualnym - blog jest określany jako gatunek hybrydyczny. Według definicji, którą można znaleźć w słowniku języka polskiego, blog jest „dziennikiem prowadzonym przez internautę na stronach www" ". Bardziej rozbudowane definicje określają blog jako „rodzaj strony internetowej zawierającej posortowane chronologicznie wpisy (notki) z możliwością komentowania ich. W przeciwieństwie do zwykłego systemu newsów (aktualności), tematyka bloga może być nieskończenie zróżnicowana: spostrzeżenia polityka, wiersze nastolatki, blog firmowy czy blog o kotach. Blogi mają zazwyczaj charakter nieformalny, pisane są potocz-

${ }^{6}$ Moda, [hasło w:] Encyklopedia PWN, http://encyklopedia.pwn.pl/haslo.php?id=3942498 (dostęp: 7.12.2017).

${ }^{7}$ D. Łukoszek, Moda, http://modologiablog.pl/2011/03/26/co-to-jest-moda (dostęp: 7.12.2017).

${ }^{8}$ F. Corner, Why Fashion Matters, London 2014.

9 Blog, [hasło w:] Słownik języka polskiego, http://sjp.pwn.pl/slowniki/blog.html (dostęp: 7.12.2017). 
nym językiem"10. Istotne dla definicji gatunku są zatem nie tylko autor, forma dzieła i narzędzie, za pomocą którego dzieło to powstaje, zwraca się także uwagę na język, chronologię, tematykę i formę podawczą treści oraz interakcję pomiędzy autorem a czytelnikiem danego bloga.

Bloger to „osoba, która prowadzi bloga, pasjonat danego tematu, który swoimi działaniami, niezależnie od wybranych form i narzędzi, dąży do zbudowania grona odbiorców wokół swojej osoby lub marki (nazwy bloga). Wszelkie działania są zaplanowane, a treści tworzone są w regularnych odstępach czasowych"11. Blog szybko i intensywnie rozwija się $\mathrm{w}$ różnych kierunkach i jest już nie tylko pamiętnikiem zapisanym w sieci, ale zmienia swój charakter z prywatnego na publiczny, gdzie zapisane notatki może przeczytać i komentować każdy użytkownik sieci ${ }^{12}$. W wyniku rozwoju mediów społecznościowych blog stracił swój charakter relacyjny. Inną ciekawą definicją bloga jest ta autorstwa Grega Myersa, który określa blog jako tekst definiowany przez jego przeznaczenie i użytkowanie, które konstruują tożsamość i więzi społeczności (a nie przez formę i zawartość). Zwraca on uwagę na aspekt wspólnotowości, którą tworzą nadawca oraz odbiorca danego bloga ${ }^{13}$.

Wraz z rozwojem mediów społecznościowych wielu blogerów zintegrowało swoje blogi z platformą Instagram, która jest miejscem, gdzie każdy zarejestrowany użytkownik może dodawać zdjęcia wraz z krótkimi opisami lub kluczowymi słowami oznaczonymi hashtagiem (\#), które mapują wszystkie zamieszczone na platformie zdjęcia. Funkcja ta daje możliwość dotarcia do osób z różnych części świata, które dzielą te same pasje czy zainteresowania. Pozwala także czerpać od nich inspiracje. Instagram jest także narzędziem dla marek, dającym możliwość szerokiej komunikacji i dotarcia do bardzo dużego grona osób, bezpośrednio zainteresowanych daną branżą czy tematyką, z pośrednio przygotowaną ofertą handlową. Jest to wciąż nowa forma komunikacji, dzięki której użytkownicy mogą w łatwy i szybki sposób dzielić się swoimi doświadczeniami z innymi użytkownikami zamieszkującymi odległe rejony świata. Instagram istnieje od października 2010 roku i jest najbardziej popularną aplikacją służącą do dzielenia się za pomocą zdjęć przeżyciami i historiami z własnego życia. Dziennie ten serwis społecznościowy odwiedza ponad 500 milionów aktywnych użytkowników, którzy umieszczają w nim średnio 250 milionów zdjęć każdego dnia ${ }^{14}$.

${ }^{10}$ Blog, [hasło w:] Słownik internetowy intensys wyjaśniający pojęcia związane z Internetem i branżą reklamową, https://slownik.intensys.pl/definicja/4/blog (dostęp: 7.12.2017).

${ }^{11}$ Kim jest Bloger, „Brief”, http://www.brief.pl/artykul,1325,kim_jest_bloger.html (dostęp: 7.12.2017).

12 A. Adamski, M. Laskowska, Nowe media - możliwości i pułapki, Poznań-Opole 2011.

13 G. Myers, The discourse of blogs and wikis, London 2010.

14 Dane opracowano na podstawie raportu DRM Instagram, https://expandedramblings.com/index.php/important-instagram-stats/ (dostęp: 7.12.2017). 


\section{Studium przypadku}

W wieku siedemnastu lat Chiara Ferragni zaczęła udostępniać swoje codzienne stylizacje $\mathrm{w}$ formie zdjęć na różnych platformach społecznościowych ${ }^{15}$ po to, by dzielić się nimi z innymi osobami oraz zobaczyć ich reakcje. Niektóre ze zdjęć były bardziej artystyczne, inne przedstawiały zestawy ubrań, które Ferragni kompletowała i prezentowała na co dzień. Od samego początku jej obserwatorzy zadawali pytania nie tylko o markę czy cenę ubrań, ale także o sposób spędzania przez nią czasu - o jej lifestyle. Ferragni chętnie odpowiadała na wszystkie komentarze, co zwiększało zasięg jej postów, w ten sposób budowała społeczność wokół własnej osoby. Riccardo Pozzoli (jej ówczesny partner życiowy i biznesowy) był zaskoczony wzrostem jej popularności. Nie potrafił wytłumaczyć jej fenomenu, który od samego początku był widoczny na wszystkich platformach, z których Ferragni korzystała. Mimo że Flickr był miejscem dla profesjonalnych fotografów, a blogerka często udostępniała zdjęcia nieprofesjonalne, to i tak cieszyły się one dużą popularnością wśród użytkowników, którzy chętnie je komentowali. Już wtedy Chiara i jej partner zaczęli rozumieć, że udostępnianie stylizacji angażuje użytkowników Internetu we wzajemną komunikację.

Ferragni na początku swojej kariery eksperymentowała i mieszała ze sobą różne style. Chciała, aby jej stylizacje docierały do większego grona odbiorców i odpowiadały na potrzeby różnych osób. Skupiała się głównie na akcesoriach, które kupowała lub pożyczała od swojej mamy, która - jak często przekonuje Ferragni - była jej największą inspiracją, jeśli chodzi o działalność w sferze mody i fotografii. Kompletowała zatem akcesoria marek luksusowych i łączyła je z ubraniami ze sklepów sieciowych (typu H\&M czy Zara).

W 2009 roku Pozzoli zaczął dostrzegać, że media społecznościowe odgrywają znaczącą rolę w biznesie w Stanach Zjednoczonych. Również Ferragni zaczęła śledzić profile blogerek modowych z USA, które już wtedy były doceniane przez branżę. Zapraszano je na pokazy, gdzie siadały w pierwszych rzędach, z których za pomocą mediów społecznościowych zdawały relacje swoim czytelnikom. W tamtych latach było to zupełną nowością, a eksperci ze świata mody uważali, że jest to tymczasowy trend, z którym nie należy wiązać przyszłości. Wstępna analiza rynku, którą przeprowadziła para, dała im motywację i inspirację do założenia własnego bloga. W ten sposób w październiku 2009 roku Chiara opublikowała pierwszy post na witrynie o nazwie theblondesalad.com ${ }^{16}$. Ferragni przyznaje, że najbardziej ekscytowało ją to, iż będzie skupiać swoich odbiorców wokół jednej platformy, na której będzie udostępniać wszystkie stylizacje, a także dzielić się z czytelnikami tym, co robi na co dzień. Na początku Ferragni publikowała swoje posty codziennie o 9.00 rano. W ten

${ }^{15}$ Początkowo były to platformy typu Flickr czy Lookbook.nu, które umożliwiają publikowane zdjęć $\mathrm{w}$ różnych obszarach tematycznych.

16 Blog istnieje od 2009 roku do dnia dzisiejszego, theblondesalad.com (dostęp: 5.03.2019). 
sposób chciała okazać lojalność wobec swoich czytelników, miało to również sprawić, iż blog stanie się ich codzienną lekturą podczas picia porannej kawy. Już po miesiącu blog odwiedzało 30 tys. użytkowników dziennie.

W 2010 roku, po trzech miesiącach działalności, Ferragni otrzymała pierwsze zaproszenie na Fashion Week w Mediolanie. W Stanach Zjednoczonych blogerki modowe były zapraszane na pokazy już kilka sezonów wcześniej, w Europie trend ten pojawił się dopiero w 2010 roku, a Ferragni była jedyną blogerką modową we Włoszech, a co za tym idzie - również jedyną na pokazach mody. To wzbudziło zainteresowanie mediów, które zaczęły wysyłać jej oferty współpracy. Chiara Ferrragni postanowiła jednak, że nie będzie z nich korzystać, ponieważ wspólnie z Pozzolinim zdecydowali, że chcą pracować w branży modowej i nie mogą pozwolić sobie na to, aby blogerka była postrzegana jako dziewczyna ze świata show businessu. Okazało się, że był to dobry wybór, wkrótce potem Ferragni zaczęła współpracować z takimi włoskimi markami jak Benetton czy Fiat ${ }^{17}$. Jednak jej ambicje sięgały znacznie dalej. Od samego początku Chiara i Pozzoli wkładali mnóstwo wysiłku, aby budować silną markę międzynarodową, a nie tylko markę włoską. Ferragni zaczęła pojawiać się na tygodniach mody w Nowym Jorku czy Paryżu. Na początku nie była na nie zapraszana, więc sama opłacała wszystkie podróże. Traktowała to jednak jako inwestycję i, co istotne, po każdym wyjeździe pozyskiwała więcej materiałów - stylizacji, zdjęć, treści, którymi mogła dzielić się na blogu, co skutkowało znaczącym wzrostem liczby czytelników. W 2011 roku Ferragni i Pozzoli postanowili utworzyć markę The Blond Salad oraz Chiara Ferragni i z tego powodu stworzyli również zespół projektowy TBS Crew (The Blonde Salad Crew), który zajmował się rozwojem brandu.

\subsection{Model Biznesowy}

\subsubsection{The Blonde Salad — blog}

W 2011 roku blog odwiedzało 70 tysięcy użytkowników dziennie. Głównym celem, jaki postawił sobie zespół projektowy TBS Crew, było ciągłe zabieganie o nowych czytelników oraz podejmowanie współpracy z kolejnymi luksusowymi markami. Zatrudniono też profesjonalną agencję, która miała udoskonalić blog wizualnie oraz stworzyć jego mobilną wersję. Zespół zdecydował się także podjąć współpracę z domem mediowym specjalizującym się w sprzedaży reklam we Włoszech. Był to dobry okres dla Ferragni, ponieważ wiele marek luksusowych nie miało jeszcze ustalonych działań e-commerce na lata 2009 i 2010. Jednak osoby odpowiedzialne za te budżety były już świadome siły Internetu i wiedziały, że warto rozpowszechnić swoją reklamę

17 Fiat to włoska marka samochodów, a Benetton to włoska marka ubrań. Blogerka współpracując z tymi markami, promowała własną osobę wśród dużej liczby odbiorców komunikatów obu brandów, szczególnie we Włoszech. 
w sieci. Jednak w tamtych latach nie wszystkie marki miały świadomość tego, czym jest blog modowy lub uznawały współpracę z blogerami modowymi za krótkotrwały trend.

Na początku blog Ferragni czerpał korzyści finansowe głównie z reklam marek w postaci banerów umieszczonych na jej stronie internetowej. Jednak zespół szybko zorientował się, że reklama w postaci lokowania produktu oraz angażujące treści przynoszą dużo lepsze rezultaty niż banery reklamowe. Wpis, który opowiadał historię o tym, jak blogerka spędziła swój dzień i który jednocześnie kierował uwagę czytelników na konkretne produkty (ubrania, akcesoria), był bardziej atrakcyjny - nie tylko dla jej czytelników, ale także dla reklamujących się brandów. Ferragni jako jedna z pierwszych blogerek zaczęła korzystać z narzędzi takich jak RewardStyle, które było platformą-łącznikiem pomiędzy blogerką a jej marką. Ujawniano tam w transparentny sposób prowizje Chiary Ferragni ze sprzedaży produktów marek, z którymi współpracowała ${ }^{18}$. Ta forma lokowania produktu zdominowała treści, które Ferragni publikowała na swoim blogu. Zespół jednak bardzo rozważnie decydował o tym, z kim chce współpracować. Odrzucano wiele ofert i wybierano tylko te, które odzwierciedlały sposób życia Ferragni. Próbowano budować trwałe wartości wokół bloga i blogerki. Zespół nie chciał dopuścić do sytuacji, w której blog mógłby stać się swoistą witryną sklepową. Ferragni uważała, iż przez to, że czytała i odpowiadała na komentarze swoich fanów, poznała ich na tyle dobrze, że wiedziała, co należy mówić do swojej publiczności, a także co oni chcą usłyszeć. Często podkreśla, że jej sukcesem jest fakt, że nie musi grać żadnej roli, a jej życie w sieci w stu procentach odzwierciedla jej życie codzienne. Kluczowe zatem dla zespołu było myślenie $\mathrm{w}$ sposób globalny i selekcja ofert współpracy z markami z różnych branż, a także budowanie długotrwałych relacji z tymi markami i z czytelnikami. Ferragni nie chciała współpracować z kimś jednorazowo. Chciała opowiadać historie, dzięki czemu mogła tworzyć projekty, przynoszące sukces zarówno marce, z którą współpracowała, jak i samej blogerce. Do takich na przykład, należy współpraca z marką Burberry w ramach, której Ferragni wypromowała pięć stylizacji, które sfotografowała na ulicach Mediolanu i systematycznie publikowała na blogu. Taka treść była dodatkową formą komunikacji, wykorzystaną $w$ trakcie wydarzenia organizowanego przez markę w ramach otwarcia dwóch nowych sklepów w Londynie i w Mediolanie. Był to jeden z pierwszych dobrze płatnych projektów, w których uczestniczyła Ferragni. Jednak, jak sama przyznaje, w dzisiejszych realiach cena takiej kampanii byłaby dużo większa, ponieważ forma jej pracy również się zmieniła. Obecnie influencerka współpracuje z profesjonalnymi fotografami, makijażystkami czy innymi

${ }^{18}$ Dzisiaj na stronie marki, w opisie na temat jej działalności, możemy znaleźć następujące informacje: „W rocznej sprzedaży detalicznej generujemy ponad 1 mld USD, łącząc marki, wpływowe i konsumenckie, dzięki sile rozproszonych oryginalnych treściach", https://www.rewardstyle.com (dostęp: 5.03.2019). 
osobami zapewniającymi jej wysoki jakościowo (pod względem estetyki) poziom treści na Instagramie. Dawniej, fotografem blogerki był jej partner, który jednocześnie pełnił funkcję managera powstającego brandu. Inną kampanią, która przyniosła jej ogromny sukces, była współpraca z Dior Cosmetiques Italy. Ferragni wraz z marką przygotowała film promujący nowe perfumy. Ferragni została również zaproszona na Cannes Film Festiwal, podczas którego pisała wiele postów na swoim blogu. Był to unikatowy projekt nie tylko dla Chiary, ale także dla czytelników jej bloga, którzy mogli „oczami Ferragni” śledzić relację z czerwonego dywanu praktycznie na żywo, co w tamtym czasie było nowym, pojawiającym się dopiero trendem.

W tym samym czasie Ferragni zaczęła pracować nad małymi kolekcjami dla marek modowych lub dzielić się swoimi wskazówkami na temat danych kolekcji ubrań czy projektować jakąś ich część. Blogerka zaprojektowała między innymi kolorową bieliznę dla marki Yamamay ${ }^{19}$, co okazało się ogromnym sukcesem sprzedażowym. Ferragni stworzyła również kolekcję obuwia dla włoskiej marki Superga i dla marki Steve Madden w Stanach Zjednoczonych (w 2013 i 2014 roku).

Wszystkie opisane powyżej działania przygotowały — pod względem finansowym — zespół Ferragni na podjęcie współpracy z markami luksusowymi, które będą zapewniać jej piękne, estetyczne treści i pozycjonować ją jako blogerkę ekskluzywną. Zespół wiedział, że marki luksusowe, takie jak Louis Vuitton, nie będą chciały płacić jej za współpracę, ale będą skłonne pokrywać na przykład koszty produkcji materiałów. Zespół Ferragni był jednak pewien, że takie współdziałanie przyniesie pożądane, długofalowe efekty, a Ferragni stanie się uznaną na świecie top blogerką.

\subsubsection{Chiara Ferragni Celebrity — marka osobista}

Wraz ze wzrostem popularności bloga, Ferragni stała się także prawdziwą gwiazdą w międzynarodowym świecie show businessu, a coraz więcej marek było skłonnych płacić jej za obecność na organizowanych przez nie wydarzeniach. $Z$ tego powodu Ferragni zdecydowała się na stworzenie osobnego zespołu, który miał zarządzać wyłącznie jej wizerunkiem jako osoby publicznej i miał działać niezależnie od bloga The Blond Salad. Zespół składał się ze specjalisty ds. projektów, specjalisty ds. PR i project managera, który był odpowiedzialny za wszystkie wyjazdy Ferragni, a także organizował jej sesje zdjęciowe, wywiady oraz wszystko, co wiązało się z jej wizerunkiem. Do 2013 roku Ferragni spędzała aż 90\% swojego czasu na podróżach do Azji, Ameryki Południowej, Stanów Zjednoczonych i Europy. Głównie było to związane z jej pracą $^{20}$. Do 2014 roku za prowadzenie wydarzeń lub pojawianie się na nich Ferragni zarobiła od 30 tys. do 50 tys. dolarów. Pozzoli przyznał, że marki były w stanie pła-

${ }^{19}$ Yamamay - marka, z którą współpracowała Chiara Ferragni, http://www.yamamay.com/en/ company.html (dostęp: grudzień 2017).

${ }^{20}$ R. Sanderson, Chiara Ferragni - the Italian influencer who built a global brand, https://www. ft.com/content/9adce87c-2879-11e9-a5ab-ff8ef2b976c7 (dostęp: 5.02.2019). 
cić Ferragni spore sumy za jej obecność na wydarzeniach, ponieważ już wtedy była ona poważaną w branży modowej blogerką i influencerką. Prawdopodobnie żadna inna osoba ze świata mody (oprócz nielicznych modelek) nie doczekała się tak dużej, globalnej rozpoznawalności. Do 2015 roku Chiara pojawiła się na czterech z pięciu okładek międzynarodowych czasopism modowych („Grazia”, „Vogue”, „Lucky”, „Instyle” oraz „Marie Claire”) ${ }^{21}$.

\subsubsection{The Chiara Ferragni Collection — marka ubrań}

Ferragni marzyła nie tylko o linii obuwia stworzonej dla innej marki, ale także o własnej marce obuwia. Pierwszy własny projekt w branży obuwniczej zrealizowała w 2011 roku, kiedy to jedna z włoskim firm zaproponowała jej współpracę. Ferragni podpisała wtedy dwuletni kontrakt, który dał jej możliwość zaprojektowania jednej pary butów w różnych kolorach. Firma miała zająć się dystrybucją i całą resztą spraw z tym związanych. Ferragni przyznaje, że nie była to jej prawdziwa kolekcja, ponieważ zaprojektowane buty nie miały kampanii reklamowej czy lookbooka. Firma odrzucała większość propozycji Ferragni i ostatecznie buty nie wyglądały tak, jak by tego chciała projektantka, co było dla niej bardzo frustrujące. Podpisany kontrakt był nieostrożnym krokiem, który ostatecznie sprawił, że nazwisko blogerki pojawiło się na produkcie, który nie do końca zgadzał się z wcześniejszym projektem. Jednak było to dla niej cenne doświadczenie, z którego wyniosła lekcję na przyszłość.

W 2013 roku, kiedy kontrakt wygasał, sklepy, które sprzedawały buty linii Ferragni, nadal zgłaszały zamówienia na jej kolekcję. Z tego powodu Ferragni zdecydowała się na znalezienie inwestora i stworzenie własnej marki obuwia. Ostatecznie wiosną 2013 roku Ferragni, Pozzoli, Barletta i Barindelli zaczęli pracować nad projektem Chiara Ferragni Collection. Podpisano kontrakt $z$ inną fabryką obuwniczą, w ramach którego Ferragni otrzymywała $\mathrm{z}$ każdej sprzedanej pary $10 \%$ marży z tytułu praw autorskich, a zespół miał kontrolę nad przebiegiem produkcji butów w fabryce. Kolekcja miała być mała, ale z silną tożsamością. Ferragni chciała kreować swoją markę pod hasłem flirting shoes (buty flirtujące), a buty miały mieć sygnet mrugającego oczka. Po premierze obuwie, a szczególnie sygnet, który się na nich znajdował, stał się ikoną jej marki. Do końca 2013 roku, w przeciągu zaledwie pięciu miesięcy, Chiara Ferragni Collection wygenerowała 50 tys. euro przychodu, a do końca 2014 roku przychód sięgnął $4 \mathrm{mln}$ euro rocznego dochodu. W lipcu 2014 roku kolekcja była dostępna w sklepie internetowym chiaraferragnicollection.com ${ }^{22}$, gdzie wygenerowała 160 tys. dolarów ze sprzedaży w przeciągu pierwszych sześciu miesięcy. Kolek-

${ }^{21}$ Wszystkie dane liczbowe zostały podane przez Chiarę Ferragni w wywiadzie udzielonym na potrzeby artykułu opublikowanego przez Harvard Business School, A. Keinan et al., op. cit.

22 Strona i sklep internetowy, na której dostępne są produkty z kolekcji Chiary Ferragni, https:// www.chiaraferragnicollection.com/eu-en/ (dostęp: 5.03.2019). 
cja jesień/zima 2014/2015 składała się z trzydziestu jeden różnych par butów w cenie od 200 do 450 dolarów i była sprzedawana w niemal dwustu sklepach w dwudziestu pięciu krajach ${ }^{23}$.

\subsubsection{Nowa strategia marki}

W drugiej połowie 2013 roku zespół zauważył, że blog The Blond Salad traci czytelników, których liczba spadła do 140 tysięcy. Blogerka przyznała, że rok 2013 był rokiem przełomowym w życiu większości blogerów modowych, a to za sprawą nowej platformy, jaką był Instagram, który stał się najczęściej używanym narzędziem do komunikacji w branży modowej. Jego prosta obsługa sprawiła, że był on dostępny dla wszystkich użytkowników sieci, którzy mogli wygodnie przeglądać treści na swoich telefonach, tabletach czy komputerach. Instagram stał się najczęściej wybieranym medium społecznościowym w branży modowej, pokonując przy tym Facebooka, Twittera, Pinterest, czy nawet same blogi modowe. Ferragni założyła swoje konto na Instagramie niemalże natychmiast, a jej treści często pokrywały się z tymi, które dodawała na blogu.

Jak sama mówi, była to dla niej niesamowita możliwość ciągłej komunikacji z fanami. Dodawała zdjęcia, filmy, a czytelnicy mogli obserwować jej życie zarówno prywatne, jak i zawodowe oraz komentować wszystkie treści w czasie rzeczywistym. Ona sama mogła obserwować inne osoby związane ze światem mody i czerpać $\mathrm{z}$ tego inspiracje. W tym samym czasie jej fani także zaczęli korzystać częściej z Instagrama i przestali odwiedzać jej bloga. Ferragni miała 2 miliony obserwujących użytkowników w 2013 roku, 3 miliony w 2014, w 2017 roku było ich ponad 11 milionów, a w 2019 już ponad 16 milionów. Zespół zrozumiał, że Chiara traci czytelników na blogu, ponieważ treści, które dodaje, były takie same na obu platformach. Zdecydowano, że The Blond Salad Blog potrzebuje nowej strategii, ponieważ fani Chiary przenieśli się bezpowrotnie na Instagram. Także w 2011 roku podczas tygodni mody poczytność bloga spadała, ponieważ czytelników nie interesowały treści z pokazów, a zachowanie i codzienne życie Chiary. Po kilku latach jej czytelnicy zmienili się i w 2014 roku byli to głównie modowi insiderzy, którzy wchodzili na bloga, ponieważ szukali treści związanych z modą. Pod koniec 2013 roku para zatrudniła Alessio Sanzogni - managera ds. komunikacji, który wcześniej pracował dla marki Louis Vuitton i współpracował z Ferragni w ramach wspólnych projektów. Miał on pomóc zespołowi w podjęciu decyzji o dalszych losach bloga. Uważał, że mimo tego, iż Ferragni od początku starannie selekcjonowała marki, z którymi chciała współpracować, to nie zawsze Chiara prezentowała się podczas realizowanych kampanii jak marka luksusowa. Chciał on więc w głównie zadbać o to, aby Ferragni była marką najwyższej klasy, z silną tożsamością, osobowością i spójnym profesjonalnym wi-

${ }^{23}$ Wszystkie dane liczbowe zostały podane przez Chiarę Ferragni w wywiadzie udzielonym na potrzeby artykułu opublikowanego przez Harvard Business School, A. Keinan et al., op. cit. 
zerunkiem. Następnym ruchem była zmiana bloga w magazyn lifestylowy. Dzięki temu, że zespół posiadał źródła, wiedzę oraz sieć kontaktów, mógł pracować nad interesującym, różnorodnym i bogatym kontentem do magazynu. W 2014 zainwestowano w rozwój zespołu: w grafika $\mathrm{z}$ większym doświadczeniem w branży modowej oraz w kilka kreatywnych osób do spraw komunikacji i marketingu. Blog zmienił się pod względem estetycznym, ale także pojawiła się na nim bardziej wyszukana treść i stał się on magazynem lifestylowym. Część treści nadal opisywała życie Chiary, popularnym tematem były także wskazówki zakupowe, inspiracje i inne treści związane $\mathrm{z}$ modą. Przyjęto taką strategię, ponieważ w przyszłości magazyn miał być niezależną od Ferragni marką. Wpisy, nad którymi pracuje zespół Ferragni, planowane są z kilkutygodniowym wyprzedzeniem, a influencerka tworzy tylko i wyłącznie dzienny kontent na platformę Instagram.

Chcąc wskazać fazy, przez które przeszedł blog i zespół tworzący markę, można wyróżnić tę, podczas której zespół Ferragni skupił się na tym, aby poprawnie komunikować to kim jest i jaka jest marka Chiara Ferragni. Od początku wszystkie działania były nakierowane na rynek globalny. Kolejnym krokiem był selektywny wybór marek, z którymi Ferragni mogłaby współpracować. Blogerce najbardziej zależało na tym, aby w każdym projekcie przedstawiać własną historię. Przykładem takiej kampanii może być chociażby projekt YSL, zrealizowany $\mathrm{w}$ ramach premiery nowych perfum Black Opium dedykowanych silnym, „luksusowym”, ale też „rockowym” kobietom. Marka YSL przeznaczyła pewien budżet na kampanię, który przekazała Ferragni. Zespół Ferragni zorganizował produkcję filmu, zdecydował, gdzie ma być wyświetlany — był zatem zarówno producentem, jak i dyrektorem kreatywnym całego przedsięwzięcia. Także Chiara Ferragni Celebirty zorganizowała wydarzenie w jednym z departamentów w Mediolanie, gdzie wraz z fanami testowała nowe perfumy. Zdecydowano również, iż magazyn „Grazia” będzie redagować i publikować teksty związane z kampanią. Projekt łączył więc kreatywne treści z cyfrowym marketingiem, relacjami prasowymi i sprzedażą detaliczną. Między innymi z tego powodu zdecydowano, że zespół Chiary Ferragni Celebrity składający się z sześciu managerów projektów, którzy zarządzali pojedynczymi projektami, będzie od teraz podzielony ze względu na zadania: media społecznościowe, edytorstwo, logistyka, asystent personalny, commercial, reklama, PR.

Trzy niezależnie działające marki odnoszące się do Chiary Ferragni miały wyznaczone trzy różne strategie rozwojowe. I tak: The Blonde Salad Blog miał przekształcić się w market/outlet z ubraniami i dodatkami. Chiara Ferragni Collection już wtedy przynosząca milionowe dochody miała rozpowszechnić swoją działalność na cały świat, przy czym zespół miał zadbać o to, aby jej produkty były dostępne tylko w wybranych, luksusowych butikach. Chciano rozwijać markę między innymi na rynkach w USA, Wielkiej Brytanii, Afryce, w Oceanii oraz w Południowej i Środkowej Ameryce. Marka była już dostępna w Meksyku i w Panamie. Należy w tym miejscu zaznaczyć, że każdy z tych krajów ma zupełnie inną specyfikę, jeśli chodzi o marketing. Konieczna jest zatem nie tylko wiedza, ale także czas potrzebny, aby wdrożyć 
projekt na tak dużą skalę. Kolekcja Ferragni miała również powiększyć się o kolejne akcesoria, takie jak obudowa na iPhone, koszulki czy czapki. Celem było zbudowanie mocnej marki, która będzie funkcjonować niezależnie od Chiara Ferragni Celebrity i The Blonde Salad. Początkowo chciano, aby marka była postrzegana jako cool brand: posiadający zdolnych projektantów, dobrą linię dystrybucyjną i kreatywną komunikację w postaci reklam. Miało to także zagwarantować, aby w przyszłości, kiedy Chiara zdecyduje się zakończyć swoją karierę jako influencerka, nie oznaczało to również zakończenia funkcjonowania marki. Nowy manager chciał jednak, aby budować synergię pomiędzy tymi trzema płaszczyznami. Tak, aby każda część marki Chiara Ferragni tworzyła spójną całość i żeby nie doprowadzić do tego, aby każda $\mathrm{z}$ tych trzech części funkcjonowała oddzielnie i rozwijała się w innym kierunku.

Z analizy sytuacji w 2017 roku wynika, że Chiara Ferragni Collection wzbogaciła swoją kolekcję o kolejne elementy takie jak: kurtki, kostiumy kąpielowe, plecaki, spodnie i spodenki, swetry, bluzy, bieliznę czy torby podróżne. Wszystkie produkty dostępne są na stronie chiaraferragnicellection.com. Chiara Ferragni (Celebrity) często promuje je na swoim Instagramie, co wskazuje, że wspomniana wcześniej synergia pomiędzy tymi dwiema osiami została zachowana. Także The Blond Salad Magazine wprowadził na swojej stronie outlet, w którym dostępne są ubrania i akcesoria różnych marek i projektantów. Obserwując blogerkę na Instagramie, można z łatwością dostrzec, że w dalszym ciągu zwiększa ona zasięg swoich marek, a liczba jej obserwatorów z każdym rokiem systematycznie wzrasta o kolejne miliony. Na platformie Chiara ujawnia każdy szczegół swojego życia. Czytelnicy Ferragni mogli być świadkami jej spektakularnych zaręczyn z włoskim raperem Fedezem czy wizyt u ginekologa, podczas których można było obserwować przebieg jej ciąży. Blogerka urodziła w 2018 roku.

2018 rok był przełomowy w życiu prywatnym Chiary. Ferragni poślubiła gwiazdę, włoskiego rapera Fedeza, a wszystkie wydarzenia $\mathrm{z}$ ich trzydniowego wesela były otagowane w mediach społecznościowym hashtagiem Ferragnez, który umożliwił pomiar zasięgu postów, które osiągnęły liczbę 67 milionów odsłon — oglądania relacji na żywo, udostępniania i czytania newsów. Para wykorzystała wydarzenie z życia prywatnego w celu wzbudzenia jeszcze większego zainteresowania marką Chiary Ferragni. Podczas wesela blogerka trzykrotnie zmieniała kreacje zaprojektowane specjalnie na tę okazję przez markę Dior. The Ferragnez - hashtag stworzony na potrzebę wydarzenia, stał się nowym członem marki Chiary Ferragni.

\section{Podsumowanie}

Mimo że pierwsze blogi modowe zostały założone w latach dwutysięcznych, a ich popularność przekroczyła najśmielsze oczekiwania, to dosyć szybko stały się one nieco przestarzałą formą komunikacji. Stało się tak za sprawą intensywnie rozwijających 
się mediów społecznościowych i kolejnych platform, takich jak Facebook, Instagram, YouTube. Blogerki modowe przeniosły swoje działania komunikacyjne na Instagram, gdzie użytkownicy śledzą ich życie prywatne i zawodowe. Sprawia to, że potrzeba pogłębiania wiedzy z dziedziny mody zanika, ponieważ treść jaką odbiorcy otrzymują na Instagramie jest dla nich wystarczająca. Z tego powodu blogerzy starannie selekcjonują treści na obu platformach oraz starają się ciągle dostarczać nowych emocji, które mają zaskakiwać, szokować lub poruszać odbiorców. Niewykluczone, że niedługo większość blogerów zacznie przekształcać swoje blogi tak, aby nie utracić grona swoich czytelników. W Polsce takie działania podjęła blogerka modowa Jessica Mercedes, która również postanowiła przekształcić swój blog w magazyn lifestylowy. Co więcej, stworzyła niezależną markę kostiumów kąpielowych, natomiast ona sama jest związana jedynie z Instagramem i profilem na YouTube, gdzie generowane są treści z jej życia prywatnego.

W jakim kierunku rozwijać się będzie blogosfera modowa? Na to pytanie nie ma jednoznacznej odpowiedzi. Trendy jednak wskazują na to, że coraz więcej blogerów przenosi swoją komunikację na inne platformy, na przykład Instagram czy wspomniany YouTube.

Chiara Ferragini jest doskonałym przykładem tego, że obserwacja i dokładne słuchanie swoich odbiorców oraz ich potrzeb, ale także zrozumienie przekształcających się mediów społecznościowych, pomaga $\mathrm{w}$ doborze odpowiednich środków i narzędzi, pozwalających na kontynuację działań w Internecie, zwiększanie ilości odbiorców oraz przekształcenie modelu biznesowego w taki sposób, aby przyniósł on jak największe zyski. Co więcej, pozwalają na to, aby medium stworzone "dla zabawy” stało się biznesem przynoszącym w walucie euro trzydziestomilionowe zyski ${ }^{24}$.

\section{Bibliografia}

Adamski A., Laskowska M., Nowe media - możliwości i pułapki, Poznań-Opole 2011.

Corner F., Why Fashion Matters, London 2014.

Cywińska-Milonas M., Blogi (ujęcie psychologiczne), [w:] Liternet. Literatura i Internet, red. P. Marecki, Kraków 2002.

Haenlein M., Kaplan A.M., Users of the world, unite! The challenges and opportunities of Social Media, „Business Horizons” 2010, nr 1 (53).

Keinan A., Maslauskaite K., Crener S., Dessain V., The Blonde Salad, Harvard Business School Case 515074, January 2015, https://cb.hbsp.harvard.edu/cbmp/content/sample/515074-PDF-ENG (dostęp: grudzień 2017).

Myers G., The Discourse of Blogs and Wikis, London 2010.

${ }^{24}$ R. Sanderson, Chiara Ferragni - the Italian influencer who built a global brand, https://www. ft.com/content/9adce87c-2879-11e9-a5ab-ff8ef2b976c7 (dostęp: 5.02.2019). 


\section{Źródła internetowe}

Blog, [hasło w:] Słownik internetowy intensys wyjaśniający pojęcia związane z Internetem i branżą reklamową, https://slownik.intensys.pl/definicja/4/blog (dostęp: 7.12.2017).

Blog, [hasło w:] Słownik języka polskiego http://sjp.pwn.pl/slowniki/blog.html (dostęp: 7.12.2017).

Faw L., Millennial Youtube star Michelle Phans' keys to success, „Forbes”, http://www.forbes.com/sites/ larissafaw/2014/06/05/millennial-youtube-star-michelle-phans-keys-to-success/ (dostęp: grudzień 2017).

Howard C., 30 under 30 who are moving the world 2015, „Forbes”, http://www.forbes.com/sites/carolinehoward/2015/01/05/30-under-30-who-are-moving-the-world-2015/ (dostęp: grudzień 2017).

Kim jest bloger, „Brief”, http://www.brief.pl/artykul,1325,kim_jest_bloger.html (dostęp: grudzień 2017).

McLeod A., Marketing Internetowy w praktyce [Internet Marketing in Practice], 2005.

Moda, [hasło w:] Słownik języka polskiego, https://sjp.pwn.pl/szukaj/moda.html (dostęp: 7.12.2017).

Larocca A., Tavi Gevinson: from fashion to Broadway, „New York Magazine”, http://nymag.com/thecut/2014/08/tavi-gevinson-from-fashion-to-broadway.html (dostęp: grudzień 2017).

Sanderson R., Chiara Ferragni - the Italian influencer who built a global brand, https://www.ft.com/ content/9adce87c-2879-11e9-a5ab-ff8ef2b976c7 (dostęp: 5.02.2019).

Strugatz R., Yi D., Incomes keep soring for fashion's top bloggers, „Women's Wear Daily”, http://www.wwd. com/wwd-publications/wwd/2014-06-12/ (dostęp: grudzień 2017).

Yamamay, strona internetowa marki, http://www.yamamay.com/en/company.html (dostęp: grudzień 2017).

\section{Chiara Ferragni - a luxury brand and an icon of the contemporary fashion world. A case study*}

Summary

The article features a case study of Chiara Ferragni, who is the world's most popular fashion blogger and influencer of our times. Based on a case study from Harvard Business School, I explain how she and her team monetize her blog and Instagram profile. Moreover, I show how they manage their brand which now includes three branches: The Blonde Salad Magazine, Chiara Ferragni Collection and Chiara Ferragni Celebrity. The business model which they used in the past has helped Chiara Ferragni to achieve her main goal which was the transformation into a luxury brand and to design her own collection of clothes.

Keywords: Chiara Ferragni, fashion, luxury brand, personal branding

* Article is based on the case study from Business Harvard School [Keinan, Anat, Kristina Maslauskaite, Sandrine Crener, and Vincent Dessain. „The Blonde Salad.” Harvard Business School Case 515074, January 2015.] 